\title{
Evaluation of the petroleum potentials and prospect of the Chad Basin Nigeria from heat flow and gravity data
}

\author{
C. N. Nwankwo • G. O. Emujakporue • \\ L. I. Nwosu
}

Received: 20 April 2011 / Accepted: 10 November 2011/Published online: 6 December 2011

(C) The Author(s) 2011. This article is published with open access at Springerlink.com

\begin{abstract}
An integrated study of the Chad Basin Nigeria has been carried out using heat flow, Bouguer gravity anomaly, depth to basement maps and interpreted seismic reflection data of the area. The seismic reflection data show two main structural elements: faults and folds whose primary structural orientation is northeast-southwest. Other features such as grabens and horst which are formed as a result of tensional stress and magnetic intrusive are also identified in the sections. The Bouger gravity anomaly ranges from -10 to -50 mgal with a northeast to southwest trend while the heat flow values ranges from 63.63 to $105.4 \mathrm{~m} \mathrm{Wm}^{-2}$ with an average of $80.6 \mathrm{~m} \mathrm{Wm}^{-2}$. The result shows that areas with relatively low heat flux in the southwest and northeast is associated with Bouguer gravity values ranging from -30 to $-50 \mathrm{mgal}$. These parts of the basin also have a higher depth to basement and are associated with low sediment, buried hills and crest of folds. The range of heat flow values computed for this study shows that the basin sediments are thermally mature and therefore has high prospects for oil and gas generation. The graben in the basin is associated with low heat flow and very low negative Bouguer gravity anomaly. The study reveals that a decrease in heat flow is observed with an increasing sedimentary thickness. Thus, by studying the heat flow map, regions of gravity highs and lows can be identified within the Chad basin. Moreover, areas of gravity lows have greater thickness of sediments than areas of gravity highs. Low geothermal gradient causes the formation of oil to begin at fairly deep subsurface levels, but
\end{abstract}

C. N. Nwankwo $(\varangle)$ · G. O. Emujakporue · L. I. Nwosu Department of Physics,

University of Port Harcourt,

Port Harcourt, Nigeria

e-mail: cyrilnn@yahoo.com makes the oil window to be quite broad. The heat flow, Bouguer gravity values and seismically determined structural features suggest that the Chad Basin Nigeria has good prospects for hydrocarbon plays in Cretaceous rocks, with high potentials for both structural and stratigraphic traps. The southwestern and northeastern axis of the basin is therefore recommended for further drilling to deeper depth based on the results of this study.

Keywords Heat flow - Gravity - Depth to basement . Hydrocarbon potential · Chad Basin

\section{Introduction}

The Chad Basin Nigeria in northeastern Nigeria is part of the Chad Basin, which extends into parts of Niger, Chad, Central African Republic, and Cameroon (Avbovbo et al. 1986). For almost three decades from now researchers and scholars on petroleum potentials in Nigeria have concentrated in the South (Niger Delta and Anambra Basins), and recently in Benue trough, while little geophysical and geological works have been carried out in the Nigerian Chad Basin in the north. The Nigerian Government has on its own demonstrated renewed efforts in the search for hydrocarbon accumulation in the basin in order to increase its oil and gas reserve base. This has, however, not been successful as no oil or gas has been discovered in a commercial quantity in the region.

The subject of integrated geophysical survey has received considerable attention in the technical literatures over the past 40 years. In petroleum exploration the combination of gravity and magnetic methods for reconnaissance survey is well established. The choice of the method for a geophysical survey is guided by a number of 
considerations such as the objective of the survey, the geology and topography of the area to be studied (Parasnis 1986).

To meet the objectives of this study, integration of heat flow, gravity, seismic reflection and depth to basement data of the Chad Basin were carried out. Heat flow data contribute towards better understanding of geologic processes like rifting, plateau uplift and mountain building as well as providing the necessary conditions for analysis of hydrocarbon maturation in sediments. In sedimentary basin, the density contrasts between the unconsolidated overburden and basement rocks can be used to determine the thickness of the sedimentary basin or the depths to the basement rocks. The thickness of a sedimentary basin has a bearing on its hydrocarbon potential. Moreover, the structural and depositional styles within a basin can be obtained from their seismic manifestations and spatial distribution.

\section{Origin, evolution and depositional history of Chad Basin}

The Chad Basin lies within a vast area of Central and West Africa at an elevation of between 200 and $500 \mathrm{~m}$ above sea level and covering $\sim 230,000 \mathrm{~km}^{2}$ (Fig. 1). The basin has been referred to as an interior sag basin (Kingston et al. 1983), due to a sagging episode that has affected it before the onset of continental separation during which a rift system junction was formed providing appropriate site for sedimentation. It, therefore, lies at the junction of basins (comprising the West African rift) which becomes active in the early Cretaceous when Gondwana started to split up into component plates (Carter et al. 1963).

Stratigraphic descriptions of the Southern Chad Basin (Nigerian sector) are available in Carter et al. (1963), Okosun (2000) and Petters and Ekweozor (1982). Sediments are mainly continental, sparsely fossiliferous, poorly sorted, and medium to coarse-grained, feldspathic sandstones called the Bima Sandstone. A transitional calcareous deposit-Gongila Formation that accompanied the onset of marine incursions into the basin, overlies the Bima Sandstones. These are overlain unconformably by graptolitic Keri-Keri Shales while the Chad Formation overlies it to the Earth's surface.

Genik (1992) presented a model for the regional framework and tectonic evolution of the CretaceousPaleogene rift basins of Niger, Chad and the Central African Republic. Both geophysical and geological interpretations of data suggest a complex series of Cretaceous grabens extending from the Benue Trough to the southwest. These data imply similar tectonic origin involving crustal thinning within and beneath the grabens and the near-surface presence of igneous intrusions within the horst/graben structures overlain by a relatively thick succession of sedimentary materials.

\section{Materials and methods}

The gravity data used for this study was modified from Cratchley as cited by Avbovbo et al. (1986). The data were
Fig. 1 Geologic map of Nigeria showing the Chad Basin (adapted from Okpikoro and Olorunniwo 2010)

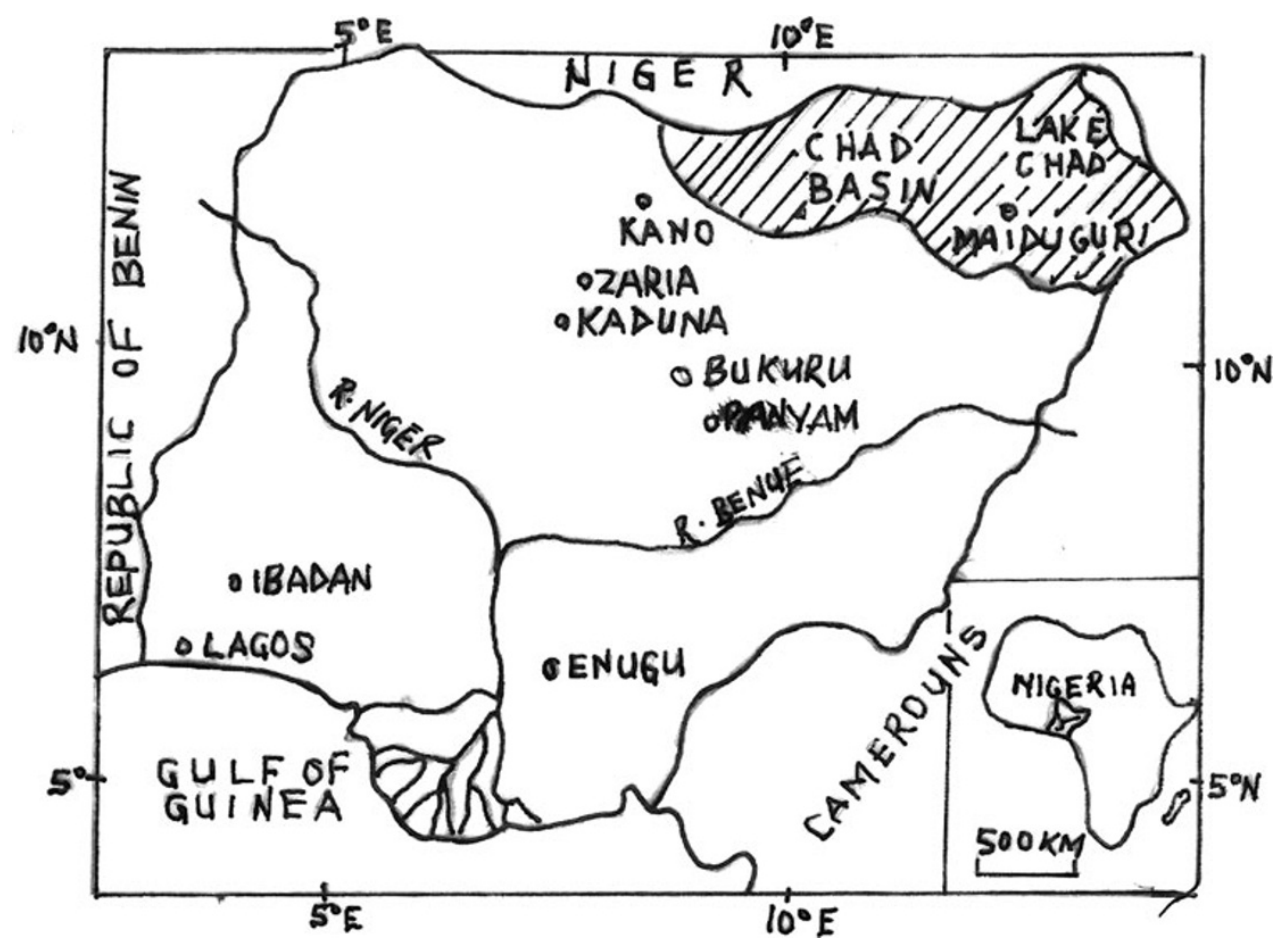


obtained with the aid of a Worden prospecting gravity meter. The Bouguer gravity anomaly map is shown in Fig. 2. A qualitative interpretation of the gravity map was carried out for the study area, and result was correlated with heat flow, depth to basement and seismic data.

The heat flow data were obtained for 14 oil wells in the Chad Basin from bottom-hole temperature data (Nwankwo et al. 2009; Nwankwo and Ekine 2009). The heat flows were calculated, after correcting for drilling effects in the well-logged bottom-hole temperatures, using the Fourier one-dimensional heat flow equation

$Q=K \frac{\mathrm{d} T}{\mathrm{~d} z}$

Where $\frac{\mathrm{d} T}{\mathrm{~d} z}=$ geothermal gradient and $K=$ thermal conductivity.

The thermal conductivity was calculated for each of the stratigraphic units for all the wells in the basin and an average values were imputed into the steady state conduction Eq. (1) to compute the heat flow values for 14 of the Wells in the basin (Table 1). The heat flow variation and the reconstructed heat flow map are shown in Figs. 3 and 4, respectively, while the depth to basement map is shown in Fig. 5. Depth to basement map of the basin was constructed from the oil wells that were drilled to basement. The seismic reflection data were obtained from the reported work of other researchers (Avbovbo et al. 1986; Okpikoro and Olorunniwo 2010). A sample of the structural interpreted seismic sections from the Chad Basin is shown in Fig. 6.

\section{Results and discussion}

The Bouguer gravity anomaly of the Chad Basin is negative (Fig. 2), with values ranging from -50 to -10 mgal. The gravity low is ovoid shape and trends northeast-southwest
Table 1 Estimated heat flow and thermal conductivity values for wells in Chad Basin

\begin{tabular}{llcl}
\hline Name & $\mathrm{K}\left(\mathrm{Wm}^{\left.-1{ }^{\circ} \mathrm{C}^{-1}\right)}\right.$ & $\mathrm{Q}\left(\mathrm{m} \mathrm{Wm}{ }^{-2}\right)$ & $\mathrm{TD}(\mathrm{m})$ \\
\hline Al-Barka-1 & 3.3 & 63.67 & 3477.6 \\
Herwa-1 & 3.5 & 104.86 & 4713.7 \\
Kanadi-1 & 3.8 & 84.33 & 3047.9 \\
Kasade-1 & 4.4 & 74.96 & 1898.0 \\
Kemar-1 & 3.7 & 75.09 & 1790.0 \\
Krumta-1 & 3.4 & 71.53 & 2950.5 \\
Masu-1 & 3.5 & 63.63 & 3100.0 \\
Mbeji-1 & 4.0 & 63.63 & 3725.7 \\
Murshe-1 & 3.0 & 83.92 & 3926.6 \\
Ngor-N 1 & 3.1 & 72.69 & 3399.2 \\
SA-1 & 3.3 & 71.24 & 2458.7 \\
Tuma-1 & 3.4 & 105.62 & 3227.6 \\
Wadi-1 & 3.2 & 86.39 & 3227.6 \\
Ziye-1 & 3.0 & 80.12 & 3358.0 \\
\hline
\end{tabular}

of the basin. The gravity contour map clearly reflects the general geologic structure of the subsurface. Gravity lows ( -10 to -25$)$ indicate basement uprisings while the very low gravity values $(-25$ to -50$)$ are caused by a northeast southwest trending elongated depression. The general structures can be ascribed to synform structure, and to a graben. The compactness of the contours within the southern part may be related to the presence of faults within the basin. These faults have a northeast-southwest trend.

The undulation of the Bouguer gravity map may also be attributed to the presence of intrusive rocks, buried bills and basement horsts. Furthermore, the undulation of contours can also be related to the presence of folds in the sediments. The amplitude of the folds increases toward southeast and decreases northwest ward. Many normal faults cut across the folds in various directions.
Fig. 2 Bouger gravity anomaly map of Chad Basin (modified from Cratchley 1960) showing Maiduguri (Chad Basin) depression

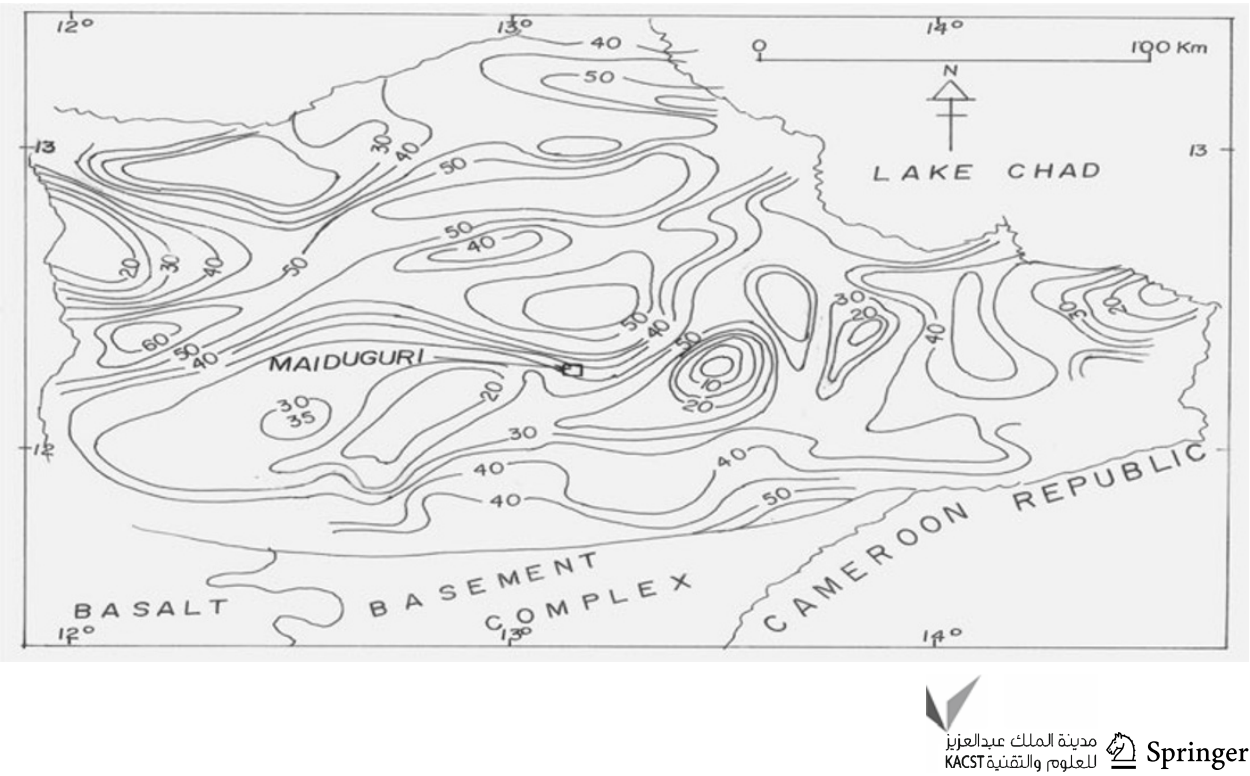




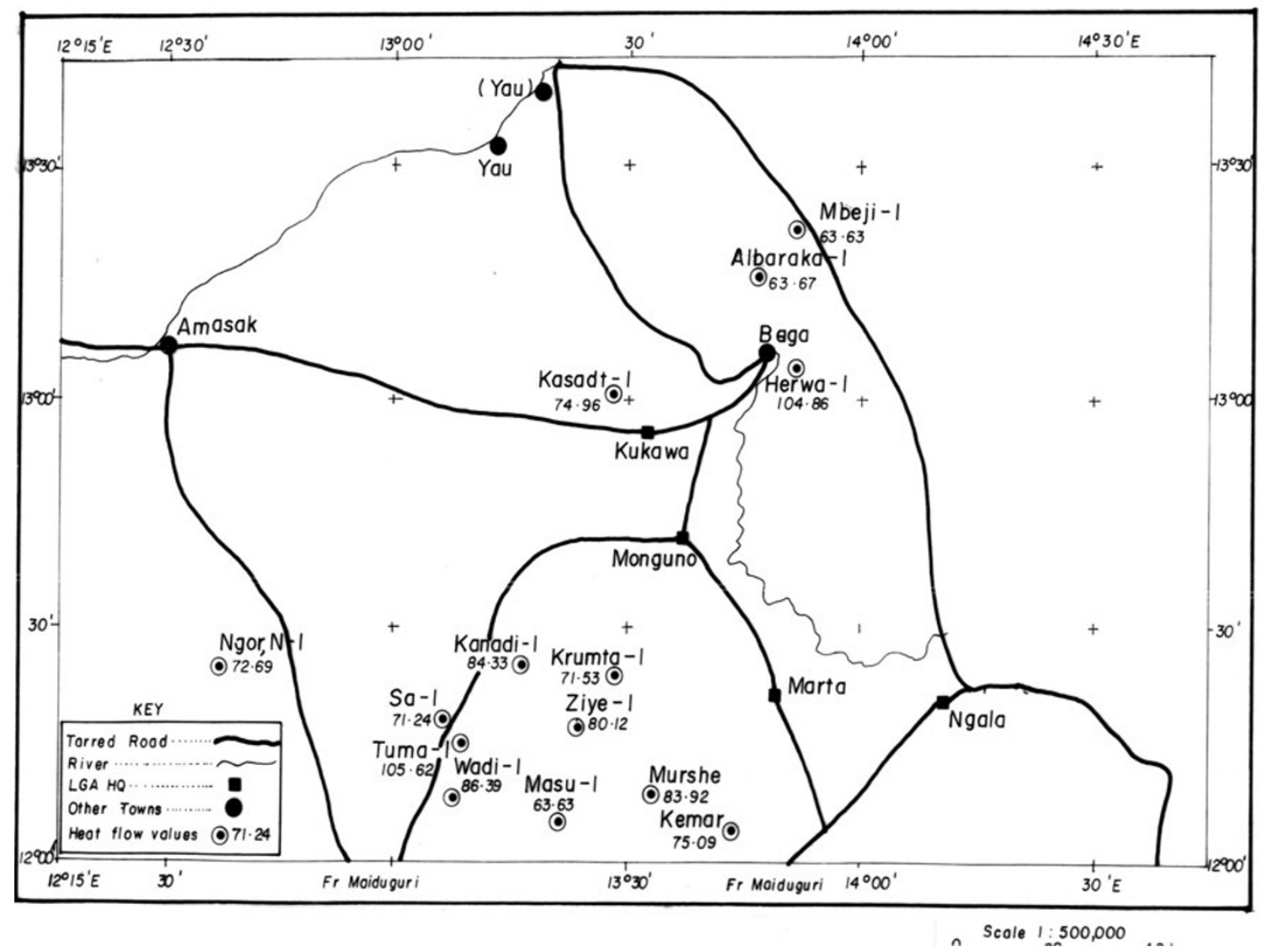

Fig. 3 Heat flow distribution for wells in the Chad Basin Nigeria

Fig. 4 Heat flow contour map of the Chad Basin Nigeria

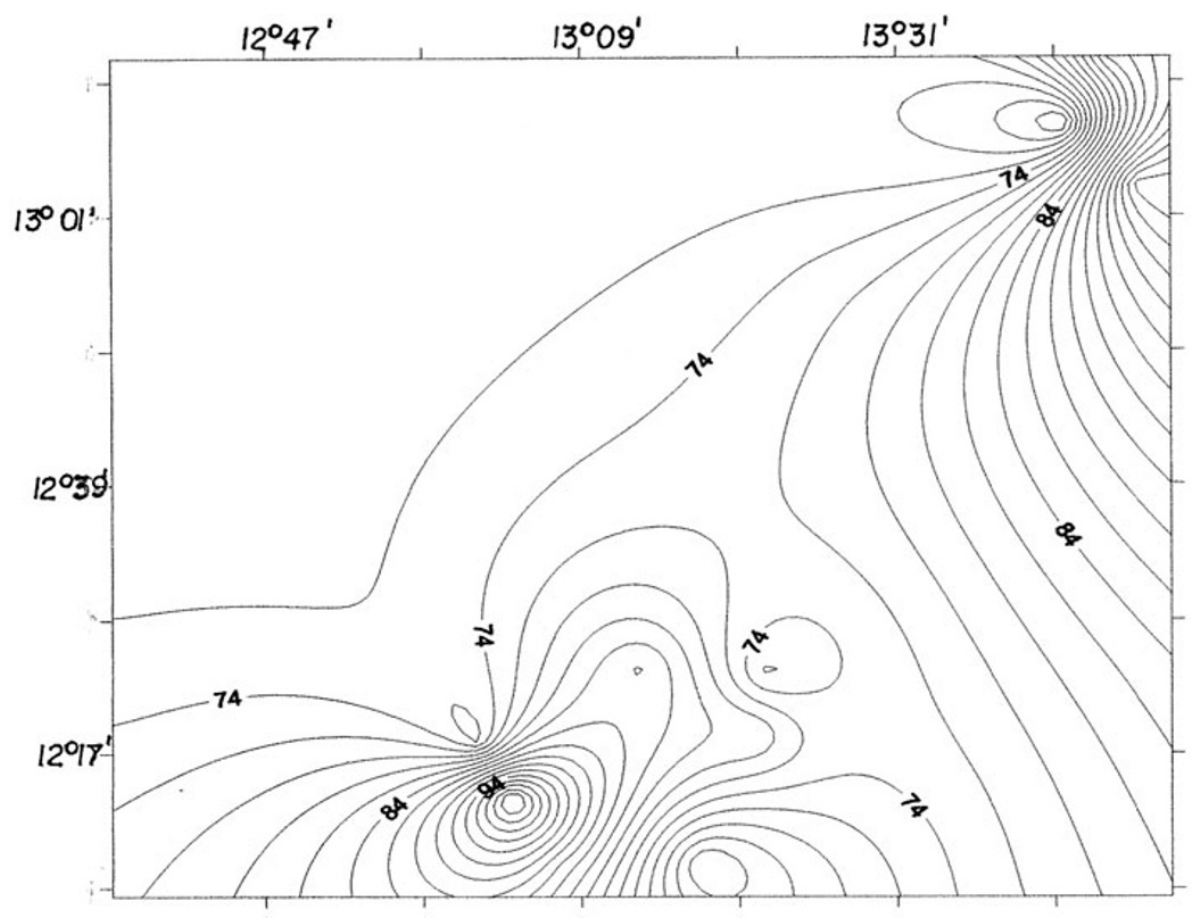




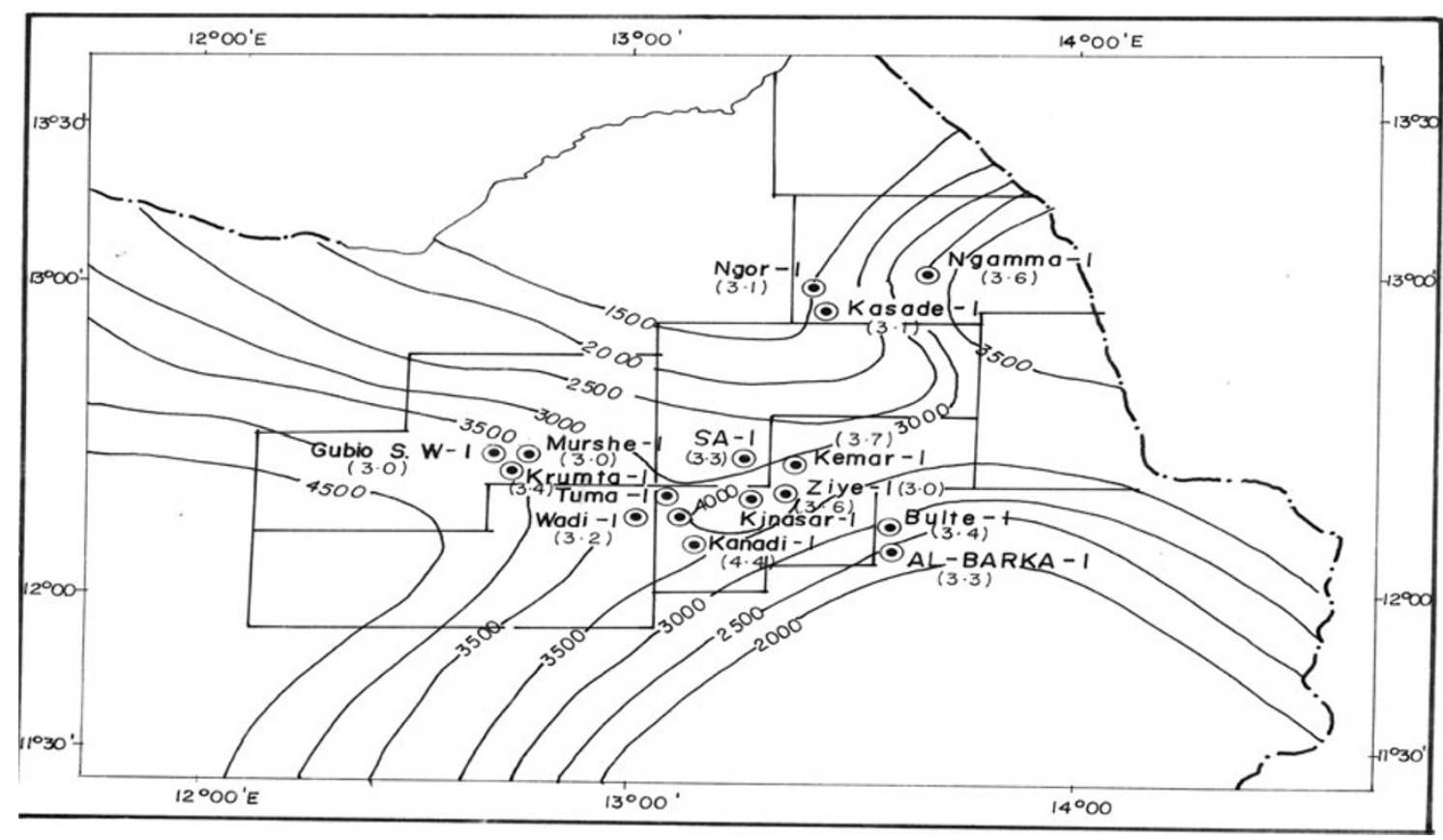

Fig. 5 Depth to basement map of Chad Basin wells in meters

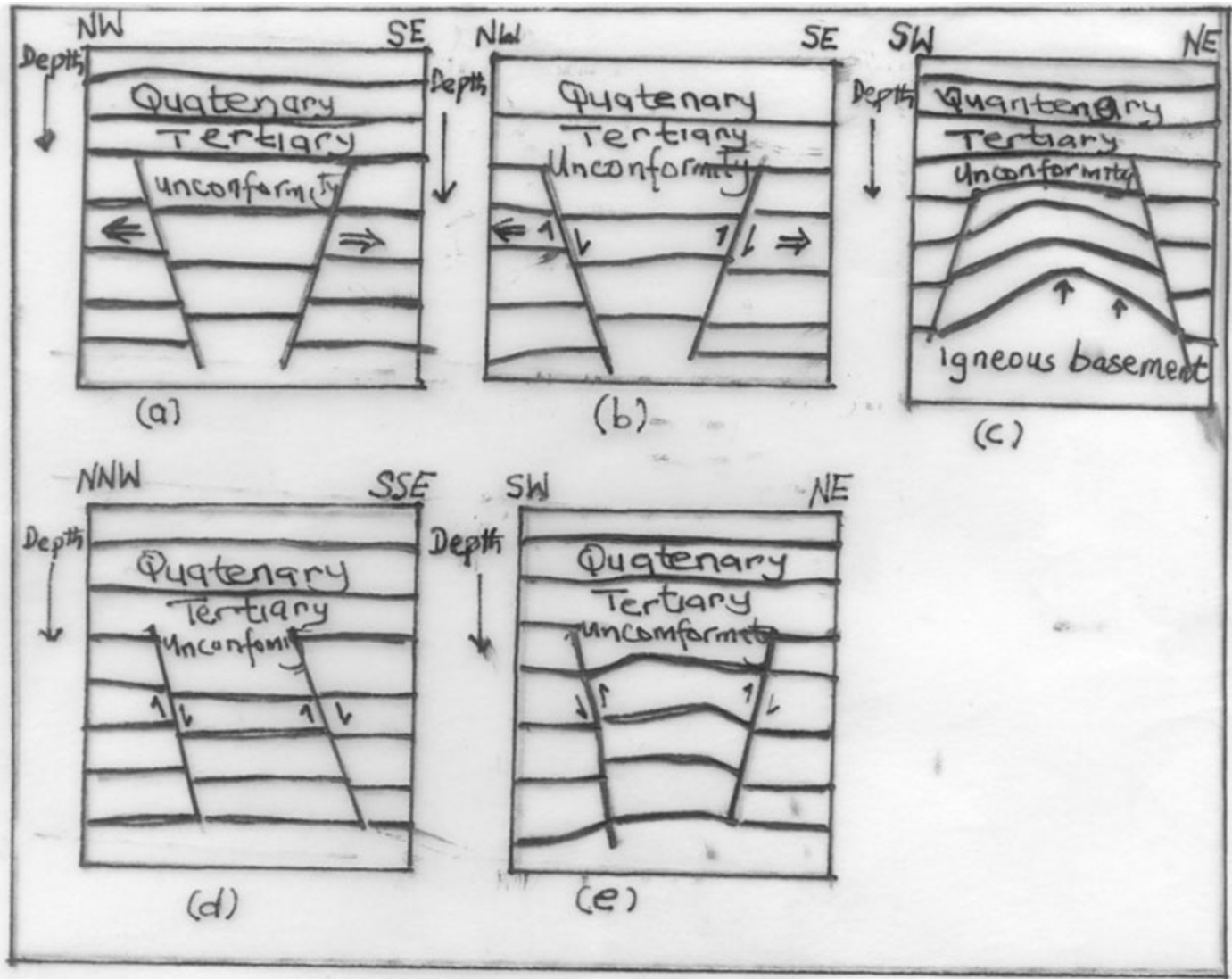

Fig. 6 Schematic illustration of common structural traps in Chad Basin Nigeria (adapted from Okpikoro and Olorunniwo 2010) 
The heat flow values vary from 63.63 for Masu-1 well to $105.62 \mathrm{~m} \mathrm{Wm}^{-2}$ for Tuma-1 well. An average heat flow density of $80.6 \mathrm{~m} \mathrm{Wm}^{-2}$ was computed for the Chad Basin. There is no distinct trend in the heat flow within the basin, although the values are relatively higher at the southwestern and northeastern axis of the basin (Fig. 3). The heat flow contour in these two areas is closely packed.

The structure in the seismic reflection data consists of faults and simple symmetrical folds, most of which have a dominant northeast-southwest trend. The fault-related features in the Chad Basin have risen from two main causes viz: those due to tensional stress which include normal faults and grabens and those due to underthrusting magmatic intrusive which includes reverse faults and horst that are closely associated with symmetrical folds. Normal faults that resulted from the tensional stress in the northwest and southeast are more abundant than reverse faults.

Comparison of the Bouguer gravity anomaly, heat flow, depth to basement maps and seismic reflection data shows that the areas with high heat flows are associated with low negative gravity values $(-10$ to -25$)$. This may be associated with buried hills, crest of folds, low sedimentary thickness or depth to basement rocks. Those areas with low heat flow and very low gravity values $(-30$ to -50$)$ are related to high sedimentary thickness, graben, and trough of the undulating folds (Fig. 4).

The computed heat flow values for all the oil wells in the basin suggest that its sediments are thermally mature enough to generate hydrocarbons. Moreover, gravity and depth to basement map reveal good sediment thickness for formations in the basin. The fault-related structures identified from seismic data have steep gradient planes which may not seal and can thus be multidirectional pathways for petroleum migration which eventually disseminated in the formations. Ofoegbu (1985) in his study of the magnetic feature of the nearby Benue Trough, observed a magnetic anomaly on a dyke-like body. Such anomalies are best accounted for to a great extent by the presence of igneous intrusive bodies of variable depth and occurring within the basement of sedimentary rocks. These intrusive which must have extended to the Chad Basin have adverse effects on the preservation of petroleum within the basin.

\section{Conclusion}

The results of the study show that areas of high heat flow $\left(>80 \mathrm{~m} \mathrm{Wm}^{-2}\right.$ ) are associated with negative Bouguer gravity anomaly $(-10$ to $-25 \mathrm{mgal})$ and low depth to basement rock $(<762 \mathrm{~m})$ while areas of low heat flow $\left(<80 \mathrm{~m} \mathrm{Wm}^{-2}\right)$ are associated with very high negative Bouguer gravity anomaly ( -30 to $-25 \mathrm{mgal}$ ) and high depth to basement rocks. This area of high sediment thickness and high heat flow should be the target for further exploration. From the seismic interpretation, the graben in the basin is associated with low heat flow and very low negative Bouguer gravity anomalies while the closely packed contours of the heat flow and gravity maps are attributed to the presence of faults and undulating folds.

The thickness of stratigraphic units, presence of source and reservoir rocks, structural related traps and heat flow values, as observed in this study are favorable criteria for high petroleum prospect. However, if the fault planes are open they unhinder conduits for petroleum migration. The intrusive could also pose severe effects on petroleum accumulation.

Acknowledgments The authors are grateful to the Nigerian National Petroleum Corporation for providing the well logs used in this study through her exploratory arm, NAPIMS Maiduguri.

Open Access This article is distributed under the terms of the Creative Commons Attribution License which permits any use, distribution and reproduction in any medium, provided the original author(s) and source are credited.

\section{References}

Avbovbo AA, Ayoola EO, Osahon SA (1986) Depositional and structural styles in Chad Basin of Northeastern Nigeria. AAPG Bull 70(121):1787-1798

Carter JD, Barber W, Tait EA (1963) The Geology of parts of Adamawa, Bauchi and Bornu provinces in north eastern Nigeria. Geol Surv Nigeria Bull 30

Cratchley CR (1960) Geophysical survey of the south-western part of the Chad Basin. In: Paper presented at Conference on Geology, Kaduna, Northern Nigeria

Genik GJ (1992) Regional framework structure and petroleum aspects of the rift basins in Niger, Chad and Central African Republic (C.A.R.). Tectonophysics 213:169-185

Kingston DR, Dishroon CP, Williams PA (1983) Hydrocarbon plays and global basin classification. AAPG Bull 67(12):2194-2197

Nwankwo CN, Ekine AS (2009) Geothermal gradients in the Chad Basin, Nigeria, from bottom hole temperature logs. Int J Phys Sci 4(12):777-783

Nwankwo CN, Ekine AS, Nwosu LI (2009) Estimation of heat flow variation in the Chad Basin Nigeria. J Appl Sci Environ Manag 13(1):73-80

Ofoegbu CO (1985) Interpretation of a linear magnetic feature near Mutum-Biyu, Nigeria. Revista Brasileira de Geofisica 3:91-97

Okosun EA (2000) A preliminary assessment of the petroleum potentials from southwest Chad Basin (Nigeria). Borno J Geol 2(2):40-50

Okpikoro FE, Olorunniwo MA (2010) Seismic sequence architecture and structural analysis of North Eastern Nigeria Chad (Bornu) Basin. Cont J Earth Sci 5(2):1-9

Parasnis DS (1986) Principles of applied geophysics, 4th edn. Chapman and Hall, USA, pp 347-350

Petters SW, Ekweozor CM (1982) Petroleum geology of Benue trough and south eastern Chad Basin Nigeria. AAPG Bull 66:1141-1149 